\title{
Novel curfew system for COVID-19 outbreak
}

\author{
Mohammad Yacoub Al Shdaifat and Abeer Adel Salih* \\ Department of Mechanical and Manufacturing Engineering, Universiti Kebangsaan Malaysia, Bangi, \\ 43600, Malaysia
}

Received: 26 March, 2021

Accepted: 07 April, 2021

Published: 10 April, 2021

*Corresponding author: Abeer Adel Salih, Department of Mechanical and Manufacturing Engineering, Universiti Kebangsaan Malaysia, Bangi, 43600, Malaysia, E-mail: abeeralnami@yahoo.com

Keywords: COVID-19; Lockdown; Curfew; Economy; Platform

https://www.peertechzpublications.com

\section{Check for updates}

\section{Abstract}

During 2020, all countries of the world imposed curfews due to the outbreak of the COVID-19 virus. However, it was observed in many countries that the curfew system is ineffective for many reasons such as instability in applying the system because there are distortions in it, randomness in making decisions related to curfews and ineffectiveness in preventing people from gathering to stop the spread of the virus. The aim of this study is to suggest a new curfew system that is more effective than the ones used in many countries now. The expected results through using this system is assisting the governments of the countries in controlling the movement of individuals, on other hand it ensures that they obtain their basic needs and the stability of commercial activities in the market.

\section{Abbreviations}

HFR: Head of the Family and Resident; II: Independent Individuals; FNLF: Foundation of Number and Location of the Families; MFA: Ministry of Foreign Affairs; DNF: Daily Number of the Families; NFDP: The Number of Families over the Day Periods

\section{Introduction}

As countries are affected by sars-COV-2 (COVID-19), many of them enforce curfews, lockdowns and social isolation for a long time to fight against the spread of the of the virus [1]. The serious public health concern is on the older adults because their heightened risk of neurocognitive, cardiovascular, autoimmune, and mental health problems [12]. During the 2019-2021 coronavirus pandemic, the term lockdown was used for actions related to mass quarantines[3].

Lockdowns can limit movements or activities in a community while allowing most organizations to function normally, or limit movements or activities such that only organizations supplying basic needs and services can function normally [4]. Experts have warned and continue to warn that using the harsh lockdown and curfew will continue to pose a threat to the lives of millions of people with potentially major disruption to an integrated world economy [5]. The purpose of this study is to create a new concept in the curfew that prevents crowding of individuals and at the same time enables them to fulfil their fundamental needs, which ensures that the commercial activity returns to the markets.

\section{Problem statement}

Many countries use different types of curfew such as: Indolence, tough and random systems. The indolence curfew allows people to stay in the markets for long time which leads to crowding and breaking the laws of the curfew.

For the tough curfew, it represents a serious risk on the feeding and the medical health of the individual, also it weakens the dynamic life of markets. Finally, Random curfew is considered as the worst system because it contains all the negative impact that mentioned in the two previous systems.

The challenge of this study is trying to find a curfew system ensures that people will not crowd in anywhere and they are able to fulfil their fundamental needs which will fresh a lot of commercial sectors. The features of this new curfew system are the stability and its efficient instructions.

\section{Determinants of the research}

The following points showing determinants of this research:

1. This curfew system is not reliable for the countries that do not have updated general statistics for the families in terms of location and number. 
2. Some heads of families who are already registered in the countries' systems are outside the country or already died, these families will not benefit from this system, but this problem can be solved through enabling them to register in the electronic platform dedicated to the curfew and enter the information of the new head of the family with mentioning one of the previous two reasons then the governments check their real state.

\section{Methodology}

\section{Distribution of heads of families}

This system depends on the general statistics of the countries for the number of families and their geographical distribution by areas. Each family in each area has specific day and time to fulfil their fundamental needs from shopping and cash withdrawal.

This method requires a set of statistical equations. First, the equation for calculating the Daily Number of the Families (DNF) who are allowed for fulfilling their fundamental needs is:

$$
D N F=\frac{\text { number of families by area }}{7}
$$

Number 7 represents the number of the week days.

For calculating the Number of Families Over the Day Periods (NFDP), the next equation is required:

$$
N F D P=\frac{D N F}{\text { number of the day periods }}
$$

Number of the day periods are determined by the countries based on the population and their situation.

Table 1 showing an example for the number of the families that can fulfill their fundamental needs by DNF and NFDP, considering that number of the day periods is 3. Generally, this methodology can be applied to countries with vastly different social systems and characteristics including urban and rural areas because this system is organized based on population of each area not based on a certain range of population, also this curfew system is independent on any local policies because it

\begin{tabular}{|c|c|c|c|c|c|}
\hline City & Sub-District & Locality & Households $^{1}$ & DNF & NFDP \\
\hline \multirow{10}{*}{ Amman } & \multirow{6}{*}{$\begin{array}{l}\text { Amman } \\
\text { Qasabah }\end{array}$} & Alabdaly & 42928 & 6133 & 2045 \\
\hline & & Ras Alain & 31481 & 4498 & 1500 \\
\hline & & Almadina & 8469 & 1210 & 404 \\
\hline & & Zahran & 29763 & 4252 & 1418 \\
\hline & & Alyarmok & 41638 & 5949 & 1983 \\
\hline & & Bader & 53788 & 7684 & 2562 \\
\hline & \multirow{4}{*}{ Marka } & Tareq & 41361 & 5909 & 1970 \\
\hline & & Marka & 35107 & 5016 & 1672 \\
\hline & & Alnaser & 59402 & 8486 & 2829 \\
\hline & & Basman & 87923 & 12561 & 4187 \\
\hline
\end{tabular}
is standalone system.

\section{Distribution of residents}

The previous methodology of distribution (in section distribution of Independent Individuals) cannot be used for residents, due to the next reasons:

1) Their condition mostly is not known for the country (if they are individuals, families or groups).

2) The places where they live are unknown.

Therefore, giving each one of the residents (above 18 years old) a day and day period to get his needs would be more easy and reliable for the governments and the residents themselves.

\section{Distribution of independent individuals}

There are citizens who are not head of family and in the same time they live individually in areas away from their families. The name of this category is Independent Individuals (II) and they represent a high percentage for some areas especially the big cities, so it is necessary to make them independent category from other categories. Independent individuals register at an online platform (which is mentioned in section instruction and discussion), so they enter all the required information then the system will give them a random day and day period.

\section{Instructions and discussions}

The principle of this new curfew system is distribution of the citizens and residents to get their needs and cash withdrawal weekly according to a specific day and time period chosen for each one of them.

The permitted shops for operating are minimarkets, supermarkets, bakeries, meat and fish stores, and fruit and vegetable shops. These shops have to operate from 8am until 12am, but they have to stop welcoming customers after each four working hours as shown in Table 2 for cleaning, reducing the proportion of the virus in the atmosphere and increase the possibility of its death, it also gives enough time for the customers to reach their homes. The individuals and companies that are working on delivering the goods to the shops must do that before 8am or during closing periods, also they must follow the preventive instructions issued by the Ministry of Health.

HFR are informed about their allowed day and time through SMS and an online platform, where the head of the family and independent individuals enter the ID number while the passport number for the resident as shown in the Figure 1. Based on the category of the person, a page will be shown contains all the information of that person as shown in Figure 2.

For II, they need to register in the online platform, then they enter the required personal information as shown in the Figure 3. The government should announce for this online platform by all the available media.

Every citizen who exits from his home must carry his identity card or passport, but residents must carry the passport In case any of HFR or II asks another person (guarantor) to 
perform the weekly shopping on his behalf, then the guarantor should carry his identity card/passport and the identity card/ passport of HFR/II.

The police and army inspect the persons by taking their personal ID or passport, then entering the online platform and entering the ID number of the head of family or the passport number of the resident to make sure that day and time gives allowance for that person. In case of II, the inspector enters the online platform and if he found that person as independent individual then the inspector compares between the location where he got inspected and the location of his family, if he was in the sub-district of his family this is a breach of the curfew. For guarantors, the inspector takes the ID card/passport of

Table 2: Periods of operating/closing the shops during the day.

\begin{tabular}{|c|c|}
\hline Time period & Shop status \\
\hline $8 a m-12 p m$ & Open \\
\hline $12 p m-2 p m$ & Closed \\
\hline $2 p m-6 p m$ & Open \\
\hline $6 p m-8 p m$ & Closed \\
\hline $8 p m-12 a m$ & Open \\
\hline
\end{tabular}

\section{ID / Passport Number}

New independent individuals ?

$$
\text { Register }
$$

Figure 1: The login page of the online platform.

\begin{tabular}{c|} 
Name \\
ID number \\
Permitted day \\
Permitted time period \\
City \\
Sub-district
\end{tabular}

Figure 2a: Head of the family page.

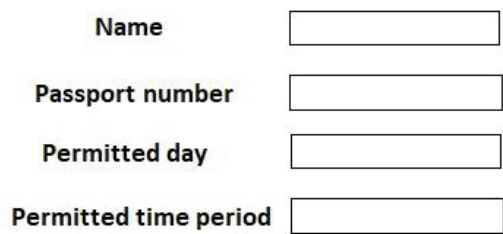

Figure 2b: Resident page.

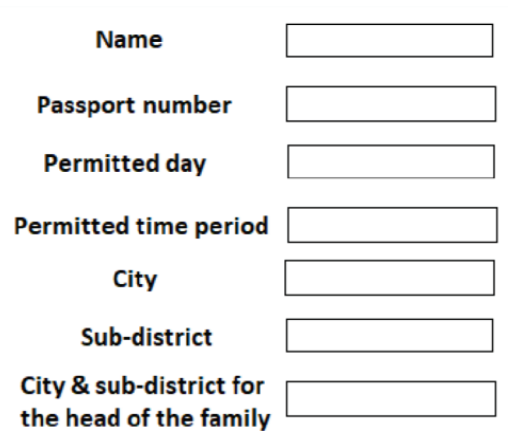

Figure 2c: Independent individual page.

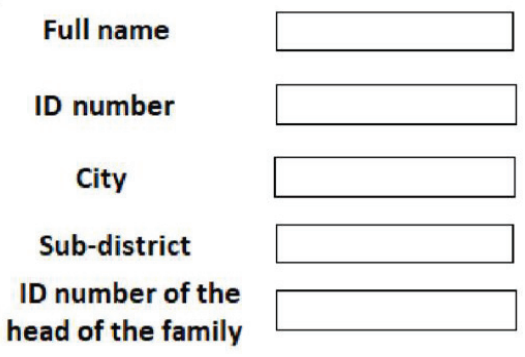

Figure 3: Registration page for the independent individuals.

the HFR/II from him and make sure that day and time gives allowance for that HFR/II, also the inspector requesting the ID card/passport of that guarantor. In addition to monitoring ATMs by bank cameras and stop them in case of irregularities or crowding of the bank clients.

It is not allowed for all to be far from their home more than a specific distance determined by the government, to ensure they return to their homes fast and not using that time for meetings or entertainment. Furthermore, informing fuel stations not to fuel the cars of individuals with more than a specified number of liters determined by the government, so that people can fulfil their needs in a way that guarantees that they are unable to reach areas far from their residence.

It is better to sterilize the money paper and coins by UV light to stop the spread of the virus [7]. Also imposing to wear a face mask and covering fruits and vegetables and emphasizing the role of personal hygiene help prevent the spread of the virus $[8,9]$. Finally, the laws of the new curfew system do not include the smart applications for delivery services.

The following points show the predicted results after applying the new curfew system:

1. This method prevents individuals from crowding when purchasing during all days of the week and for all specified time periods.

2. Ensuring that the commercial activity returns to the markets in a manner that does not allow the spread of infection among individuals.

3. This method works for the convenience of the police and army through reducing the interaction between 
them and the number of individuals who are out of their homes.

4. This method guarantees the presence of various highquality goods throughout the permissible shopping periods during the day instead of overcrowding, which only remains the poor goods that some individuals will have to purchase to meet their needs if any.

5. An individual may become infected with the virus when he leaves the house, but this method ensures that he stays at home for 6 days, so probably the initial symptoms will appear on him during this period, which precipitates his quarantine.

\section{Conclusion}

There are a lot of curfew systems in various countries of the world, but many of these have problems such as instability, floundering, not meeting the needs of people and ineffective in preventing people from crowding out to stop the spread of the virus [10-12], so it was planned to work on a new curfew system that has advantages over the other systems. Furthermore, this system can keep the commercial activities in the market so it prevents the sharp negative impact on the economy. This new curfew system can be applied to countries with various social systems and characteristics including urban and rural.

\section{Author contributions}

Mohammed Yacoub Al-Shdaifat wrote the original draft of this manuscript and visualized the result. Abeer Adel Salih wrote part of the manuscript. All authors have read and agreed to the published version of the manuscript.

\section{Acknowledgment}

We would like to acknowledgment the help with insightful edits from university kebangsaan Malaysia.

\section{References}

1. Richard A, Nellums LB (2020) COVID-19 and the consequences of isolating the elderly. Lancet Public Health 5: e256. Link: https://bit.ly/3cXF0qA

2. Gerst-Emerson K, Jayawardhana $\mathrm{J}$ (2015) Loneliness as a public health issue: the impact of loneliness on health care utilization among older adults. Am J Public Health 105: 1013-1019. Link: https://bit.ly/2PKYoxU

3. Naushad K, Shah F, Shah F, Naushad M (2020) Quarantine Role in the Control of Corona Virus in the World and Its Impact on the World Economy. 46. Link: https://bit.ly/2RdNscK

4. Wang C, Cheng Z, Yue X McAleer M (2020) Risk Management of COVID-19 by Universities in China. Multidisciplinary Digital Publishing Institute 13. Link: https://bit.ly/3cXFpt6

5. McKibbin WJ, Fernando R (2020) The global macroeconomic impacts of COVID-19: Seven scenarios. CAMA Working Paper 45. Link: https://bit.ly/3msPRMb
6. Department of statistics/Hashemite kingdom of Jordan (2019) Estimated population of the kingdom by governorate, gender and families for 2019. 1-40.

7. Iwaguch S, Matsumura K, Tokuoka Y, Wakui S, Kawashima N (2002) Sterilization system using microwave and UV light. Colloids and Surfaces B: Biointerfaces 25: 299-304. Link: https://bit.ly/3uvhG9r

8. Chiu NC, Chi H, Tai YL, Peng CC, Tseng CY, et al. (2020) Impact of wearing masks, hand hygiene, and social distancing on influenza, enterovirus, and allcause pneumonia during the coronavirus pandemic: Retrospective national epidemiological surveillance study. J Med Internet Res 22: e21257. Link: https://bit.ly/2Q3uW6a

9. Lo SH, Lin CY, Hung CT, He JJ, Lu PL (2021) The impact of universal face masking and enhanced hand hygiene for COVID-19 disease prevention on the incidence of hospital-acquired infections in a Taiwanese hospital. Int $\mathrm{J}$ Infect Dis 104: 15-18. Link: https://bit.ly/3sZBUHU

10. Board E (2020) Opinion: Sweden's anti-lockdown experiment flopped. Now it faces a wave of pandemic pain. Link: https://wapo.st/3dHGSTI

11. Koh D (2020) COVID-19 lockdowns throughout the world. Occup Med 70: 322. Link: https://bit.ly/3s080XA

12. Rear J (2020) The messy reality of the 10pm curfew: my disappointing Saturday night out in Soho. Link: https://bit.ly/2Q1 Jlun

Discover a bigger Impact and Visibility of your article publication with

\section{Peertechz Publications}

\section{Highlights}

* Signatory publisher of ORCID

* Signatory Publisher of DORA (San Francisco Declaration on Research Assessment)

- Articles archived in worlds' renowned service providers such as Portico, CNKI, AGRIS, TDNet, Base (Bielefeld University Library), CrossRef, Scilit, J-Gate etc.

* Journals indexed in ICMJE, SHERPA/ROMEO, Google Scholar etc.

* OAI-PMH (Open Archives Initiative Protocol for Metadata Harvesting)

* Dedicated Editorial Board for every journal

* Accurate and rapid peer-review process

* Increased citations of published articles through promotions

- Reduced timeline for article publication

Submit your articles and experience a new surge in publication services (https://www.peertechz.com/submission).

Copyright: @ 2021 Al Shdaifat MY, et al. This is an open-access article distributed under the terms of the Creative Commons Attribution License, which permits unrestricted use, distribution, and reproduction in any medium, provided the original author and source are credited. 